\title{
Article \\ Integrated Climate Action Planning (ICLAP) in Asia-Pacific Cities: Analytical Modelling for Collaborative Decision Making
}

\author{
Mahendra Sethi ${ }^{1,2, *}$, Li-Jing Liu ${ }^{3,4}$, Eva Ayaragarnchanakul ${ }^{2,5}{ }^{(0}$, Aki Suwa ${ }^{6}$, Ram Avtar ${ }^{7}\left(\mathbb{D}\right.$, Akhilesh Surjan ${ }^{8}$ \\ and Shilpi Mittal ${ }^{1,9}$
}

check for

updates

Citation: Sethi, M.; Liu, L.-J.; Ayaragarnchanakul, E.; Suwa, A.; Avtar, R.; Surjan, A.; Mittal, S. Integrated Climate Action Planning (ICLAP) in Asia-Pacific Cities: Analytical Modelling for Collaborative Decision Making. Atmosphere 2022, 13, 247. https: / / doi.org/10.3390/atmos13020247

Academic Editors: Miao Yu and Yong Wang

Received: 30 December 2021

Accepted: 28 January 2022

Published: 31 January 2022

Publisher's Note: MDPI stays neutral with regard to jurisdictional claims in published maps and institutional affiliations.

Copyright: (c) 2022 by the authors. Licensee MDPI, Basel, Switzerland. This article is an open access article distributed under the terms and conditions of the Creative Commons Attribution (CC BY) license (https:/ / creativecommons.org/licenses/by/ $4.0 /)$.
1 Indian Society for Applied Research \& Development, New Delhi 110092, India; shilmittal@gmail.com

2 Sustainability Economics of Human Settlements, Technical University Berlin, 10623 Berlin, Germany; eva.a@psu.ac.th

3 Center for Energy and Environmental Policy Research, Beijing Institute of Technology, Beijing 100081, China; liulijing@bit.edu.cn

4 School of Management and Economics, Beijing Institute of Technology, Beijing 100081, China

5 Faculty of Economics, Prince of Songkla University, Songkhla 90110, Thailand

6 Faculty of Contemporary Society, Kyoto Women's University, Kyoto 605-8501, Japan; suwa@kyoto-wu.ac.jp

7 Faculty of Environmental Earth Science, Hokkaido University, Sapporo 060-0810, Japan; ram@ees.hokudai.ac.jp

8 Humanitarian, Emergency and Disaster Management Studies Program, Charles Darwin University, Darwin, NT 0810, Australia; Akhilesh.Surjan@cdu.edu.au

9 Department of Architecture \& Planning, GD Goenka University, Gurugram 122103, India

* Correspondence: mahendrasethi@hotmail.com

\begin{abstract}
While climate change has global causations and impacts, there is growing consensus on addressing the $2{ }^{\circ} \mathrm{C}$ challenge through local actions. However, at the local level, there is disintegrated knowledge on the following: (a) short-, mid- and long-term climate vulnerability, (b) economy and GHG structures and their future pathways, and (c) useful mitigation and adaptation undertaken elsewhere. We evaluate these gaps through a comprehensive review of scientific literature and policy approaches of urban-climate studies in the Asia-Pacific Region. Based on the research findings, we develop a collaborative research framework of an integrated climate action planning (ICLAP) model for evidence-based decision-making tool. It adopts an innovative methodology integrating knowledge and data from diverse analytics, as follows: (a) spatial: downscaling global/regional climate scenarios to forecast local climate variability $(50 \mathrm{~km} \times 50 \mathrm{~km})$ for 2030 (SDG target) and 2050; (b) statistical: a meta-analysis of 49 five-million-plus cities to forecast economic, energy and GHG scenarios; (c) bibliometric: a systematic review of global urban climate interventions from Google Scholar that collectively aid cities on policy inputs for mid-term climate variability, GHG profiles and available solutions at their disposal. We conclude with a discussion on scientific and policy relevance of such a tool in fostering overall urban, regional and global sustainability.
\end{abstract}

Keywords: integrated model; climate action planning; urban climate; Asia-Pacific; decision making

\section{Introduction}

The year 2020 was one of the three warmest years on record, despite a cooling La Niña event. In fact, 2011-2020 was the warmest decade on record, in which the six years since 2015 have been the hottest [1]. The climate change phenomenon has global greenhouse gas (GHG) contributions and implications; yet there is a growing and unequivocal consensus that the $2{ }^{\circ} \mathrm{C}$ global warming challenge can be dealt with concerted local actions [2-4]. In fact, there is a high confidence in understanding amongst scientists that pathways limiting global warming to $1.5^{\circ} \mathrm{C}$, with no or limited overshoot, would require rapid and far-reaching transitions in energy, land, urban areas and infrastructure (including transport and buildings), and industrial systems [5]. During the COP26, the Asia-Pacific Climate Week 2021 sends a strong signal to how the Asia-Pacific region presents some 
unique challenges in achieving global climate mitigation and adaptation goals. The region is responsible for a significant proportion of the global emissions, being one of the most rapidly developing economies and emitting over half of the world's GHGs. In addition, it is home to most of the world's low-lying cities [6]. In terms of climate vulnerability, of 100 cities facing the greatest environmental risks, 99 are in Asia, including 37 in China and 43 in India [7]. The risks are from a combination of pollution, extreme heat stress, natural hazards and vulnerability to climate change, and are concomitant with growing GHGs. Bangkok, Dhaka, Guangzhou, Ho Chi Minh City, Kolkata, Manila, Mumbai, Shanghai, and Yangon are all highly vulnerable to rising sea levels, floods, and other climate impacts [8]. Meanwhile, Australians are increasingly exposed to excess weather extremes especially heat, resulting in social, economic and health impacts [9]. The local governments in Asia-Pacific cities face triple challenge of addressing local economic development goals in improving standards of living, abatement of air-pollution and GHG emissions, as well as protecting their citizens from extreme climate events [10]. While there is a growing body of scientific research into global climate change at the regional level, there is a high degree of complexity, uncertainty, variability and fragmentation of knowledge that cities have about their climate policy [11]. Through a scientific grant project, we aim to develop a collaborative research framework of an integrated climate action planning (ICLAP) model for a first-of-its-kind evidence-based decision-making tool in Asia-Pacific cities. While pursuing this research, we acknowledge the variation of datasets, approaches and methods followed by these cities (elaborated in Section 2) that influences their understanding on mitigation responsibilities, adaptation requirements and expected measures, as well as responses of other cities facing similar challenges. The crucial question is as follows: how do we bridge the noted gaps in urban climate research with greater scientific collaboration and integration efforts for action-oriented decision making by the Asia-Pacific cities? In order to pursue this inquiry, we formulate a probe into the fragmentation of urban climate methods and approaches in scientific literature (Section 2) to devise a collaborative research framework, an innovative analytical model that integrates disparate approaches across diverse disciples (Section 3). We test its applicability over a sample of major cities in the Asia-Pacific region (Section 4) to conclude with major findings that underpin the relevance and implications of developing a collaborative and integrated tool meant for urban climate action decision making.

\section{Review of Methodologies in Urban Climate Planning}

The concept of integrated planning has been included in the Paris Agreement [4] and the UNFCCC's AR5 Report [12]. Yet, scientific studies offer different interpretations and applications of an integrated approach, and their degree/scale of involvement and benefits in climate action also differ. Most interpret integration as a combination of different activities or sectors within mitigation and adaptation verticals. In mitigation, these include combining the study of controlling GHG emissions with reducing local pollutants (e.g., $\mathrm{SO}_{2}, \mathrm{NOx}$, $\mathrm{CO}$, and $\mathrm{PM}$ ) or combining policies of energy conservation, transportation, climate change and air pollutant control $[13,14]$. In adaptation, an integrated approach largely focuses on impacts, vulnerability and adaptation, or socio-economic development, environmental conservation and disaster risk reduction [15], or enhancing benefits by using socio-ecological systems to enhance governance, adaptive capacity and resilience [16]. However, this offers a limited understanding of 'integration', leaving out mitigation and adaptation as two distinct tasks to be tackled conjunctively as local action. In addition, even while considering the two most prominent climate paradigms - mitigation and adaptation-evidence-based knowledge from different case studies or best practices remains missing, particularly for local action [17-19]. Urban climate models and tools are a growing and noteworthy technique to bridge the gap between global climate goals, national economic objectives and local development priorities, thereby resulting in multiple benefits. The Covenant of Mayors, with 10,774 signatories representing the over 328 million population of Europe, has urban governments sharing their key actions, supported by a Good Practices database 
that documents achievements, case studies, city profiles, and videos of climate-friendly projects from these cities [20]. Yet, there are several conceptual, methodological, empirical, and policy-governance gaps in their practical implementation on the ground [12,21]. The conceptual gap fundamentally arises because of different theoretical constructs of key issues and interpretations in this multi-disciplinary area. Gaps in assessment methods and tools are because of blurred objectivity and precision in climate analysis, particularly at the sub-national level. This leads to creating a larger gap in generating sufficient empirical information on climate action in cities. A paucity of credible evidence impinges on scientific policy application.

The science-policy gap is further widened by public policies heavily influenced by pure economic paradigms to improve development indices. Most local governments in Asia-Pacific cities face triple pressures of addressing national economic and climate goals, local development priorities to improve standards of living, and protecting their citizens from extreme climate events and environmental pollution [22,23]. In the absence of complete empirical knowledge about their climate vulnerabilities, energy and emission contributions, and how other cities approach similar situations, climate action planning in local governance is quite tentative and non-structured. Contemporary research informs us that science-based climate action planning in cities is grossly complicated and uncertain [11], largely driven by the following three specific approaches (Figure 1): (1) a spatial approach that determines climate variability and hazard vulnerability for disaster mitigation, adaptation needs and resilience measures, (2) a statistical modelling approach that hinges on demographic and economic analysis and the forecasting of energy consumption and GHGs to guide strategies for low-carbon societies; (3) a case study approach that qualitatively draws on best practices, learning, etc. from individual cities or a group of cities to inform policy actions in other similar situations.

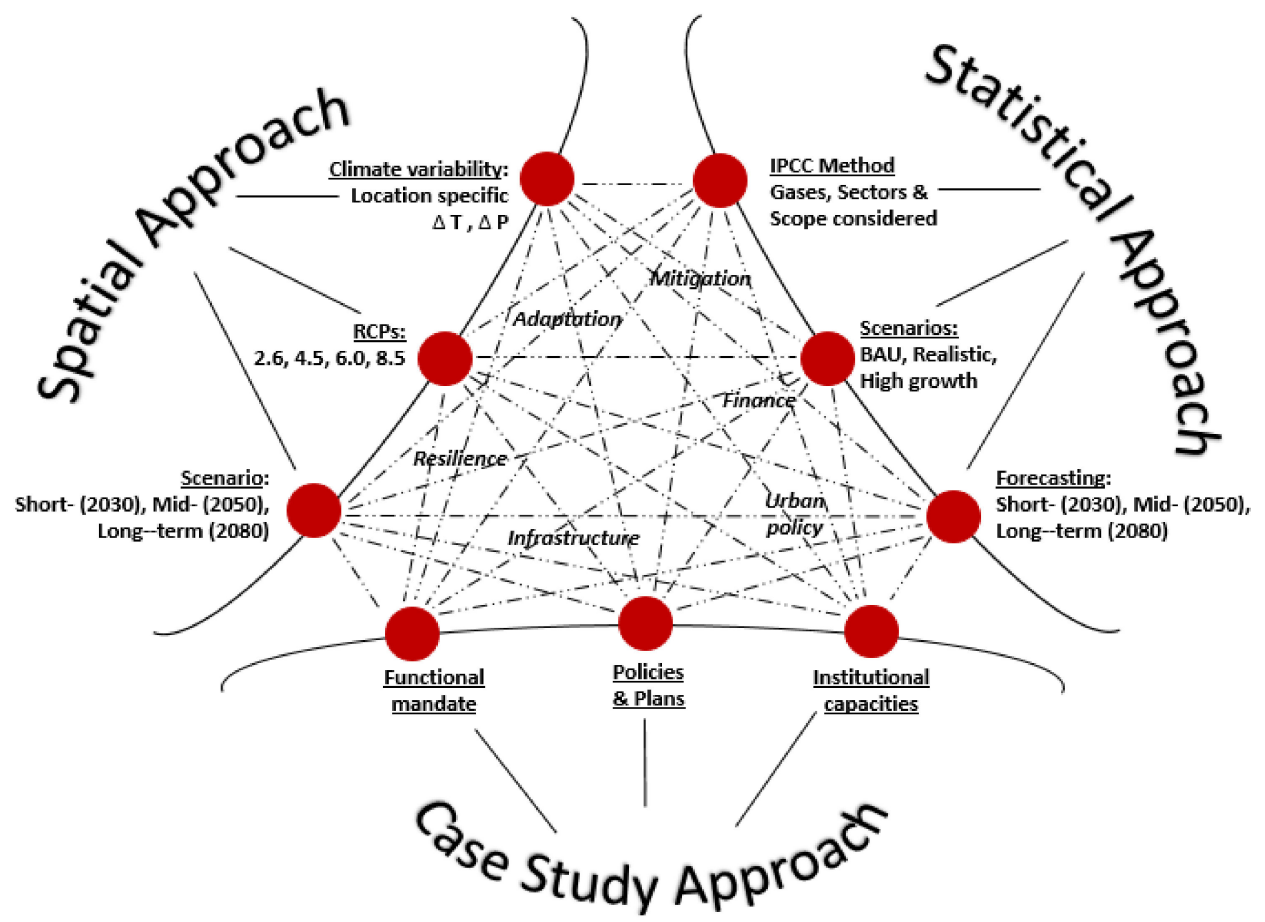

Figure 1. The complexity, variability and fragmentation of knowledge and information while adopting spatial, statistical and case study approaches in urban climate action planning.

A bibliometric survey of urban climate research in the Asia-Pacific region conducted for peer-reviewed papers in the Google Scholar database in March 2021 (Table 1) demonstrates this fragmentation. The survey used the keywords 'urban-climate', 'Asia', 'Pacific', and 'cities' in the query generating a total of 3840 papers. In the next stage, the titles and abstracts 
of these papers were further screened for their method/approach using the additional filter keywords 'spatial', 'statistical' and 'case study', singularly and in combination with each other. This stage significantly reduced the results (203 titles), exhibiting that most urban climate studies in the Asia-Pacific region follow the statistical approach (83). These essentially report and project urban economic and GHG profiles but do not inform on climate vulnerabilities. The next most common approach used is the case study approach (80), which mainly provides inputs on urban interventions towards concerted climate action. This is followed by the use of the spatial approach (39), which essentially analyzes climate variabilities to map hazard-prone areas and risks. Most notably, there is not a single study that uses a combination of all three approaches. There is only one study that uses a combination of two approaches (spatial and case study) [24]. Analyzing US states (Florida, Pennsylvania, Washington) and EU countries' (Denmark, Hungary, Portugal) legislation, policy and case law, legal and multidisciplinary literature worldwide, as well as national and local climate vulnerabilities, this research demonstrates how urban governance can become more adaptive.

Table 1. The number of peer-reviewed papers and top-10 cited papers as per relevance, adopting spatial, statistical and case study approach in urban climate research in the Asia-Pacific region. Source: Google Scholar 2021.

\begin{tabular}{cccc}
\hline \multicolumn{4}{c}{$\begin{array}{c}\text { Keywords: Urban-Climate, Asia, Pacific, Cities } \\
\text { Sample Size }=\mathbf{3 8 4 0 ,} \text { Results: 203 }\end{array}$} \\
\hline & Spatial Approach & Statistical Approach & Case Study Approach \\
\hline \multirow{2}{*}{ Spatial approach } & 39 & 0 & 0 \\
\hline \multirow{2}{*}{ Statistical approach } & 0 & 83 & 1 \\
& {$[25-34]$} & {$[35-44]$} & {$[24]$} \\
\hline \multirow{2}{*}{ Case Study approach } & 0 & 1 & 80 \\
& 0 & {$[24]$} & {$[45-54]$} \\
\hline
\end{tabular}

The fragmentation in conceptualization and assessment of urban climate concerns is evident in sponsored research too. For instance, there is a high degree of variation in application of the 'integrated approach' in projects supported by notable regional organizations such as the Asia-Pacific Network (APN). Out of 25 projects explicitly containing 'integrated' in their title, 15 pertain to climate adaptation, 6 to climate mitigation while only 4 projects deal with both [55-58], of which only the last two actually develop decisionmaking tools. Here, the study convenes scholars from different disciplines and contexts to discuss strategies for incorporating resilience thinking and climate change adaptation and mitigation into urban decision-making and planning process. [57] It encourages participants to actively engage in the development of the resilience assessment framework, identifying and prioritizing resilience criteria, and also the inter-linkages between these, to form a toolkit. The other research develops a co-evolutionary urban climate change decision-support system to assess the climate change impact and risk for health, transport and water, using a participatory assessment approach [58]. Both studies emphasize more on adaptation-centric decision making with methods based on experts' perception and ranking of adaptation needs and resilience. This is imperative, but only a piece of the entire jigsaw puzzle for local authorities to empirically ascertain their entire climate responsibilities and requirements, and responses of other cities facing similar challenges to prioritize their own climate responses. This leads to several research questions related to urban climate action plans (CAP) remaining unanswered, most important of which are the following: (1) what are the different datasets available in cities to create an urban CAP? (2) What is the scope of the CAP mitigation, adaptation or both of the strategies? (3) Does the city CAP account for multiple-ranged climate scenarios for, e.g., 2030, 2050, 2080, etc.? (4) Which of the following approaches or methods does the CAP document follow: spatial, statistical, or case study? 
(5) Are there any major gaps observed in conceptualization or application of urban climate research? These questions are addressed by conceptualizing an integrated framework and analytical model, outlined further in Section 3.

\section{ICLAP-Outlining Research Framework and Analytical Model}

\subsection{Need and Research Objects of an Integrated Model}

Based on the review of scientific literature on approaches and methodologies, it is clear that there is a high degree of fragmentation in urban climate planning, raising some crucial knowledge gaps that impede and delay local action, notably non-availability of reliable empirical information on the following: (a) short-, mid- and long-term climate vulnerability scenarios at sub-national level; (b) how variedly different societies contribute to climate change regarding their GHG structures; (c) what useful climate actions local governments are taking across the globe. In order to address the above challenge in the Asia-Pacific region, there is an apparent need to introduce Integrated Climate Action Planning (ICLAP) - a simulation-based decision-making model (Figure 2) that can assimilate useful information about climate mitigation, adaptation and best practices. The model uses an integrated approach to produce reliable policy alternatives considering projected climate variability, customized GHG targets and synthesis of ex-post policy solutions, in an intricate yet easy to use the apparatus.

One such attempt to measure and understand global human settlement patterns and processes, elaborate [59] on how introducing technologies underpinning an urban thematic platform that facilitates the use of earth observation (technologies) through web-based services [60]. It aims at different user communities addressing settlement analysis and decision making, and it supports three types of uses. First, it provides a computing space for image processing specialists to process large data volumes and data streams; second, it provides access to open information products on settlements grouped under specific windows; third, it facilitates the dissemination of information and results to potential decision makers. It is further argued that integrating information from different datasets expands the possibility to meet the demand for data required in modelling physical and sociodemographic processes on climate emissions, urban land expansion and economic growth. For example, settlement information can be integrated with material and energy flows to address the sustainability of resources, including energy, water and food. Environmental resilience information combined with settlement information is used to derive policies of adaptation to global environmental change. Settlement information can be integrated with that of particulate matter concentration to assess air quality in cities across the globe and the hazard to human health that it generates. The spatial extent of settlements can be used to store a number of attributes such as those made available by the city database [61]. At the same time, this platform lacks incorporation of future climate variability (temperature rise and precipitation changes) and best practices relevant for adaptation and resilience at the urban scale.

In order to achieve a comprehensive science-based decision-making model, the aim of a collaborative research on ICLAP is to prepare a tool that includes mitigation and adaptation considerations, as well as evidence in the form of case studies from practice. The research addresses the following specific objectives:

1. To integrate knowledge from the following three different knowledge domains (disciplines): climate variability (climate science, spatial studies), quantitative data of Asia-Pacific cities (social science, environmental science) and published literature of case studies/best practices (data science/bibliometric).

2. Trend analysis and scenario making, as follows: to determine the current situation, trends and forecast of (a) local climate scenarios, and (b) city GHG profiles for 2030 (SDG target year) and 2050.

3. To systematically review best practices, policies and case study literature on local climate actions. 
4. To coalesce all synthesized information at an appropriate scale for practical application in designing an easy-to-use ICLAP tool that enables the decision-making process at city level.

5. To demonstrate how the ICLAP can be utilized by policy makers and relevant stakeholders for developing a road map (strategic plan) of selected cities, up to 2030 and 2050.
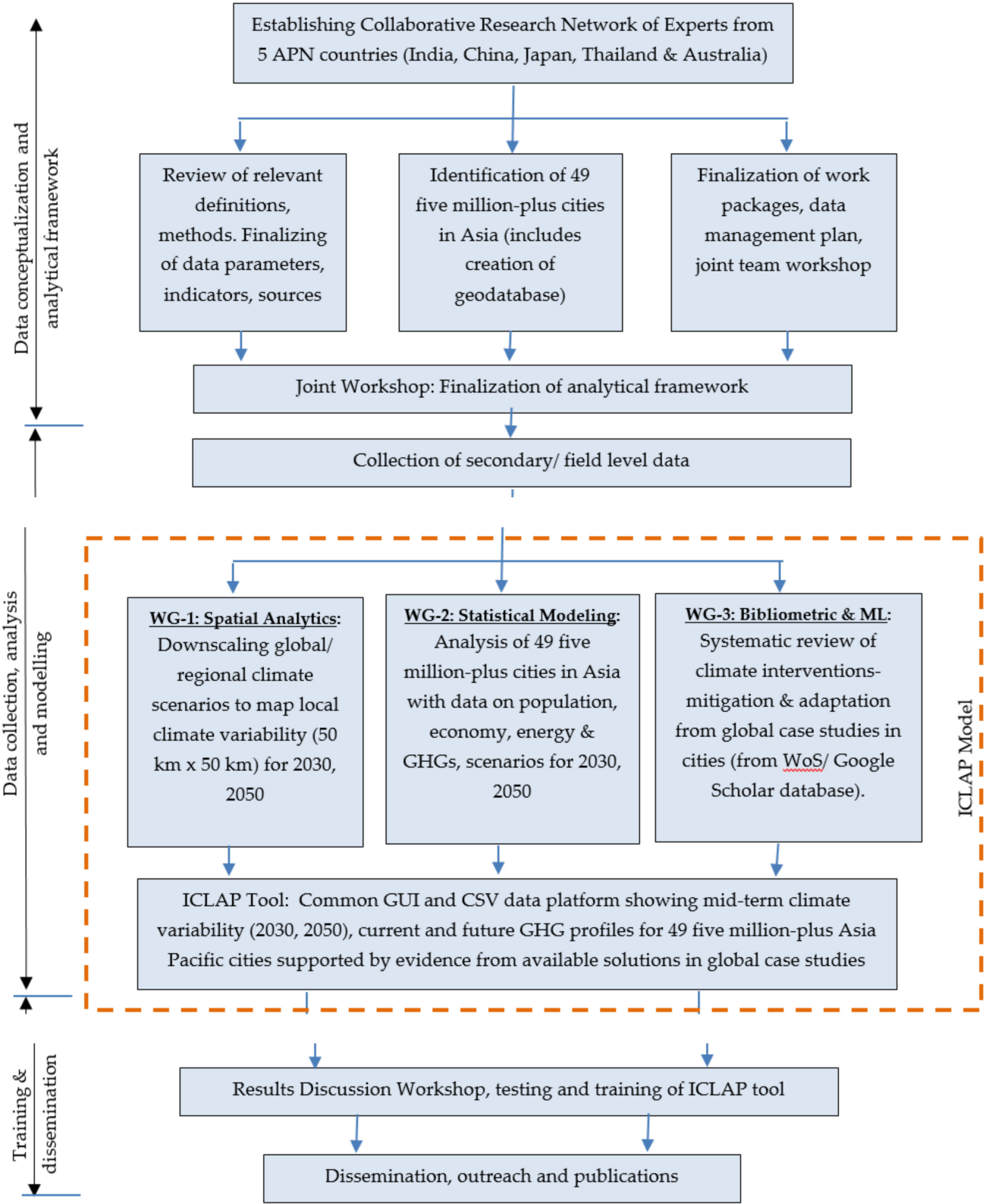

Figure 2. Integrated climate action planning (ICLAP) methodology.

\subsection{Data and Methods}

For the purposes of this research, we scan the standard World Urbanization Prospects dataset on urban agglomerations [62] to shortlist 49 five-million-plus cities that represent the most populated and rapidly developing cities in the Asia-Pacific region (Supplementary Table S1). In order to include a sample of cities from the Australian continent within the Asia-Pacific region, we purposefully include Melbourne $(4,967,733)$ and Sydney $(4,925,987)$, which are about to enter the five-million-population club. Thus, our sample of cities span across 16 countries, mostly in China (20) and India (9), followed by two each in Japan, Bangladesh, Pakistan and Australia. Many international frameworks-the Sustainable 
Development Goals [3], the Sendai Framework for Disaster Risk Reduction [63], the Paris Agreement [4], and the New Urban Agenda [64]—require human settlements information to feed indicators. Based on the literature, we identify necessary indicators and sources for urban data, socio-economic data, energy and GHG data and urban climate plans (Table 2), which are extracted from city-specific agencies. Data on urban areas, builtup areas, urban population (gridded), etc. is deduced from a consistent source, namely the Global Human Settlement Layer Urban Centres Database (GHS-UCDB), a project supported by the European Commission, which is the most complete database on cities to date, publicly released as an open and free dataset. Urban centers are defined in a consistent way across geographical locations and over time, applying the "Global Definition of Cities and Settlements" developed by the European Union to the Global Human Settlement Layer Built-up (GHS-BUILT) areas and Population (GHS-POP) grids [65]. The dataset offers the location of each city, their extent (surface, shape), and describes each city with a set of geographical, socio-economic and environmental attributes for multiple data points spanning 25-40 years in time. The first stage of the analyses selects cities across the Asia-Pacific for their data availability and knowledge integration. This demands careful interpretation of urban datasets and CAPs published in regional languages; thus, 17 cities have been selected by contributing researchers (authors) in their respective country/subregion, the findings of which are discussed in Section 4.

Table 2. Inventory with identified indicators and sources for urban data, socio-economic data, energy/GHG data and urban climate plans (filled for the sample city of New Delhi).

\begin{tabular}{|c|c|c|c|c|c|c|}
\hline & \multirow[b]{2}{*}{ Indicators } & \multirow[b]{2}{*}{ Identified Sources } & \multicolumn{4}{|c|}{ Data Collected for a Sample City of New Delhi } \\
\hline & & & Data & Unit & Year & Source \\
\hline \multirow{5}{*}{ 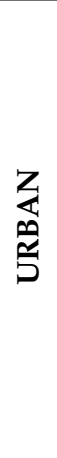 } & Urban Population & From national census & $16,349,831$ & & 2011 & $\begin{array}{c}\text { Census of India } \\
2011\end{array}$ \\
\hline & Urban Area & From master plan & 1483 & $\mathrm{sq} \mathrm{km}$ & 2021 & $\begin{array}{l}\text { Master Plan of } \\
\text { Delhi } 2021\end{array}$ \\
\hline & Built-up Area & $\mathrm{NO}$ & 1212.73 & $\mathrm{sq} \mathrm{km}$ & 2015 & GHSL \\
\hline & Municipal Area & $\begin{array}{l}\text { webpage of the } \\
\text { municipality }\end{array}$ & 1482.71 & $\mathrm{sq} \mathrm{km}$ & & $\begin{array}{c}\text { From City } \\
\text { Development } \\
\text { Plan, JNNURM }\end{array}$ \\
\hline & Metropolitan Area & From regional plan & 2000 & $\mathrm{sq} \mathrm{km}$ & 2021 & $\begin{array}{c}\text { NCR Plan 2021, } \\
\text { NCRPB }\end{array}$ \\
\hline \multirow{5}{*}{ 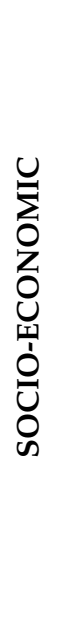 } & $\begin{array}{c}\text { GDP (nomi- } \\
\text { nal/gross/net) }\end{array}$ & $\mathrm{NO}$ & 263 & USD billion & 2015 & GHSL \\
\hline & $\begin{array}{c}\text { Household in- } \\
\text { come/expenditure }\end{array}$ & $\begin{array}{c}\text { From } \\
\text { economics/statistics } \\
\text { dep of state/city }\end{array}$ & 3705 & INR & 2018 & DoES (GNCTD) \\
\hline & $\begin{array}{c}\text { Workforce or } \\
\text { labour } \\
\text { participation rate }\end{array}$ & $\begin{array}{c}\text { From } \\
\text { economics/statistics } \\
\text { dep of state/city }\end{array}$ & 334 & $\%$ & 2011-12 & DoES (GNCTD) \\
\hline & $\begin{array}{l}\text { Education level } \\
\text { (\% of graduates) }\end{array}$ & $\begin{array}{c}\text { From } \\
\text { education/statistics } \\
\text { dep of state/city }\end{array}$ & 28.2 & $\%$ & 2017-18 & DoES (GNCTD) \\
\hline & $\begin{array}{c}\text { Healthcare } \\
\text { (Number of Hospi- } \\
\text { tals/doctors/beds/ } \\
1000 \text { pop) }\end{array}$ & $\begin{array}{c}\text { From } \\
\text { health/statistics dep } \\
\text { of state/city }\end{array}$ & 2.74 & & 2019 & $\begin{array}{c}\text { Economic survey } \\
\text { of Delhi 2020-21, } \\
\text { Dte. of Health } \\
\text { Services, GNCTD }\end{array}$ \\
\hline
\end{tabular}


Table 2. Cont.

\begin{tabular}{|c|c|c|c|c|c|c|}
\hline \multirow{7}{*}{ 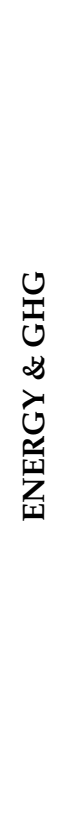 } & $\begin{array}{c}\text { Energy } \\
(\mathrm{EJ} / \mathrm{MtoE} / \mathrm{MW} / \mathrm{MWh})\end{array}$ & $\begin{array}{c}\text { From urban } \\
\text { energy/electricity } \\
\text { department }\end{array}$ & 37.91 & Million ton & 2014 & $\begin{array}{l}\text { Delhi State Action } \\
\text { Plan on Climate } \\
\text { Change, Govt. of } \\
\text { NCT of Delhi }\end{array}$ \\
\hline & $\begin{array}{l}\text { Total emissions } \\
\left(\mathrm{CO}_{2} \text { or } \mathrm{CO}_{2} \mathrm{e}\right)\end{array}$ & $\begin{array}{l}\text { From climate } \\
\text { inventory/plan or a } \\
\text { GHG inventory } \\
\text { consistent at the } \\
\text { regional-level }\end{array}$ & & & & GHSL \\
\hline & $\begin{array}{l}\text { Industrial } \\
\text { emissions }\end{array}$ & do & 18.23 & $\begin{array}{c}\text { Million } \\
\text { tons/person/year }\end{array}$ & 2012 & do \\
\hline & Energy emissions & do & 23.1 & $\begin{array}{c}\text { Million } \\
\text { tons/person/year }\end{array}$ & do & do \\
\hline & $\begin{array}{l}\text { Buildings } \\
\text { emissions }\end{array}$ & do & 9.74 & $\begin{array}{c}\text { Million } \\
\text { tons/person/year }\end{array}$ & do & do \\
\hline & $\begin{array}{l}\text { Transport } \\
\text { emissions }\end{array}$ & do & 2.91 & $\begin{array}{c}\text { Million } \\
\text { tons/person/year }\end{array}$ & do & do \\
\hline & $\begin{array}{c}\text { AFOLU/LULUCF } \\
\text { emissions }\end{array}$ & do & 85.69 & Kilotons/person/year & do & do \\
\hline \multirow{6}{*}{ 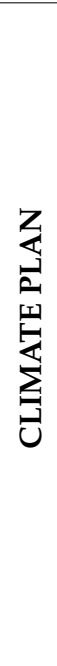 } & Approach & $\begin{array}{c}\text { From climate action } \\
\text { plan/strategy } \\
\text { document }\end{array}$ & $\mathrm{Sp}, \mathrm{St}$ & $x$ & $x$ & $\begin{array}{c}\text { Dept of } \\
\text { Environment, Govt. } \\
\text { of NCT of Delhi }\end{array}$ \\
\hline & $\begin{array}{l}\text { Climate scenarios } \\
\text { (years) }\end{array}$ & do & 2030, 2050, 2080 & $x$ & $x$ & $\begin{array}{l}\text { From Delhi State } \\
\text { Action Plan on } \\
\text { Climate Change }\end{array}$ \\
\hline & $\begin{array}{l}\text { GHG scenario } \\
\text { (years) }\end{array}$ & do & & $x$ & $x$ & do \\
\hline & $\begin{array}{c}\text { Mitigation strategy } \\
(\mathrm{Y} / \mathrm{N})\end{array}$ & do & $\mathrm{Y}$ & $\mathrm{x}$ & $\mathrm{x}$ & do \\
\hline & $\begin{array}{c}\text { Adaptation } \\
\text { strategy }(\mathrm{Y} / \mathrm{N})\end{array}$ & $\mathrm{NO}$ & Y & $\mathrm{x}$ & $\mathrm{x}$ & \\
\hline & $\begin{array}{l}\text { Resilience strategy } \\
(\mathrm{Y} / \mathrm{N})\end{array}$ & $\begin{array}{c}\text { From climate action } \\
\text { plan/strategy } \\
\text { document }\end{array}$ & $\mathrm{N}$ & $x$ & $\mathrm{x}$ & do \\
\hline
\end{tabular}

\subsection{The ICLAP Model}

The ICLAP tool adopts advanced modelling of synthesizing three different knowledge domains/analytics, building on specific and accepted research methods in the respective domains of climate adaptation, mitigation and data science, as elaborated below:

1. Spatial—downscaling climate scenarios and GIS mapping of variability: in order to ensure that the research can be used for multi-disciplinary applications, our study focuses on demonstrating fundamental climate variability scenarios over the space than defines vulnerability class, weight assignment and/or mapping vulnerability. To project climate variabilities at the sub-national/urban level, we intend to downscale temperature and rainfall anomalies from global/regional MRI-CGCM3 and MICROC5 (RCPs 4.5 and 8.5 scenario) to a scale of $50 \mathrm{~km} \times 50 \mathrm{~km}$ for 2030 and 2050 [66]. These climate variability maps are instrumental in drafting climate adaptation strategies.

2. Statistical — trend analysis of urban indicators and GHG forecasts: the potential climate mitigation analysis is to be supported by bottom-up projections of city data profiles, 
considering demography, economic structures, energy consumption, buildings, waste, transport, and GHGs using CGE equilibrium modelling for 2030 and 2050 [67]. In this model, we intend to develop several GHG profiles-current, business-as-usual (BAU) and high-growth scenarios-for 2030 (SDG target year) and 2050 to guide mitigation strategies.

3. Bibliometric-meta-analysis of evidence from case studies: data science and machine learning methods are to be used for systematic review of global case studies in local climate action. It employs Web of Science, a Google Scholar-like database, to conduct a bibliometric analysis, followed by a meta-analysis of key policy solutions $[14,68,69]$ while coding for diverse GHG sectors (energy, industry, transport, LULUCF, waste, etc.), ex-post policy solutions, their relative efficiency and most importantly governance modes [70], i.e., regulations, enabling mechanisms, economic instruments and voluntary measures.

The ICLAP model incorporates all the distinctive features of a tool, as follows: database (hyperlinked references of ex-post policy case studies), evaluation (setting of standard and customizable features in extracting information on downscaled GIS scenarios, GHG models and urban climate solutions), as well as their simulation (of GHG projections and RCP scenarios). The process of integrating data structures is executable on a web-based digital platform, a portal/application that supports data files in comma-separated values (CSV), shape file (SHP) and image (JPEG/JPG) formats over a graphical user interface (GUI).

\section{Results Discussion}

Here, we process and report urban datasets and CAPs of cities in selected AsiaPacific countries to assess the disintegration of knowledge in the inter-disciplines of urban climates. The analysis is conducted over live/concurrent CAPs for the 17 selected AsiaPacific cities in the period February-July 2021 by team members (contributing authors) in their respective countries/regions, through an exhaustive checklist. The team collected and studied 121 documents, reports, datasets, etc. and their full results (duly referenced) are collated in Supplementary Table S2. Here, we present summary findings (Table 3), reporting these for Australian, Chinese, Indian, Japanese and SE Asian cities, followed by a general discussion.

Australian cities: In spite of having specific metropolitan plans, Sydney and Melbourne draw from a comprehensive national census for demographic and socio-economic data and State level database for energy consumption. The Melbourne City Council (MCC) has separate mitigation and adaptation strategy documents. With 2015 as the baseline, the mitigation strategy considers GHG projections for 2025, 2030 and 2050 under 'business as usual', 'significant action', 'accelerated action' and 'purchasing offsets' scenarios [71]. It further creates four strategic priorities including 100 per cent renewable energy, zero emissions buildings and precincts, zero emissions transport, and reducing the impact of waste, all supported by cost-benefit ratio assessments. On the other hand, the city's adaptation strategy is a refresh version of the 2009 policy that identifies critical risks for now, 2030 and 2070, including heat waves, droughts, flooding, and sea level rise [72]. It devises strategies enhancing the natural environment and greens spaces, built form and urban renewal, building community resilience, and protecting the diverse economy. On the other hand, Sydney does not have a designated CAP but a Draft Environmental Strategy (DES) 2021-2025 [73]. Instead of putting forth measurable, reportable and verifiable (MRV) methods for scenario-making and target-setting of GHGs, the DES sets unsubstantiated targets of 70\% GHG reduction by 2030 from a 2006 baseline, net-zero emissions by 2035, and $50 \%$ of electricity demand met by renewable sources by 2030 . The identification of climate-induced risks in the city and planned adaptive measures to respond to the possible impacts are completely missing. 
Table 3. The variability of data, information and plans in the urban climate domain of Asia-Pacific cities.

\begin{tabular}{llllllllllll}
\hline City/Country & \multicolumn{4}{c}{ Demographic and Socio-Economic Data } & Urban Data & Energy Data & $\begin{array}{c}\text { GHG } \\
\text { Inventory }\end{array} \begin{array}{c}\text { Climate } \\
\text { Action Plan }\end{array}$ \\
\hline & 1 & 2 & 3 & 4 & 5 & 6 & 7 & 8 &
\end{tabular}

\begin{tabular}{c|c|c|}
\hline Australia & \\
\hline Sydney & & \\
\hline Melbourne &
\end{tabular}
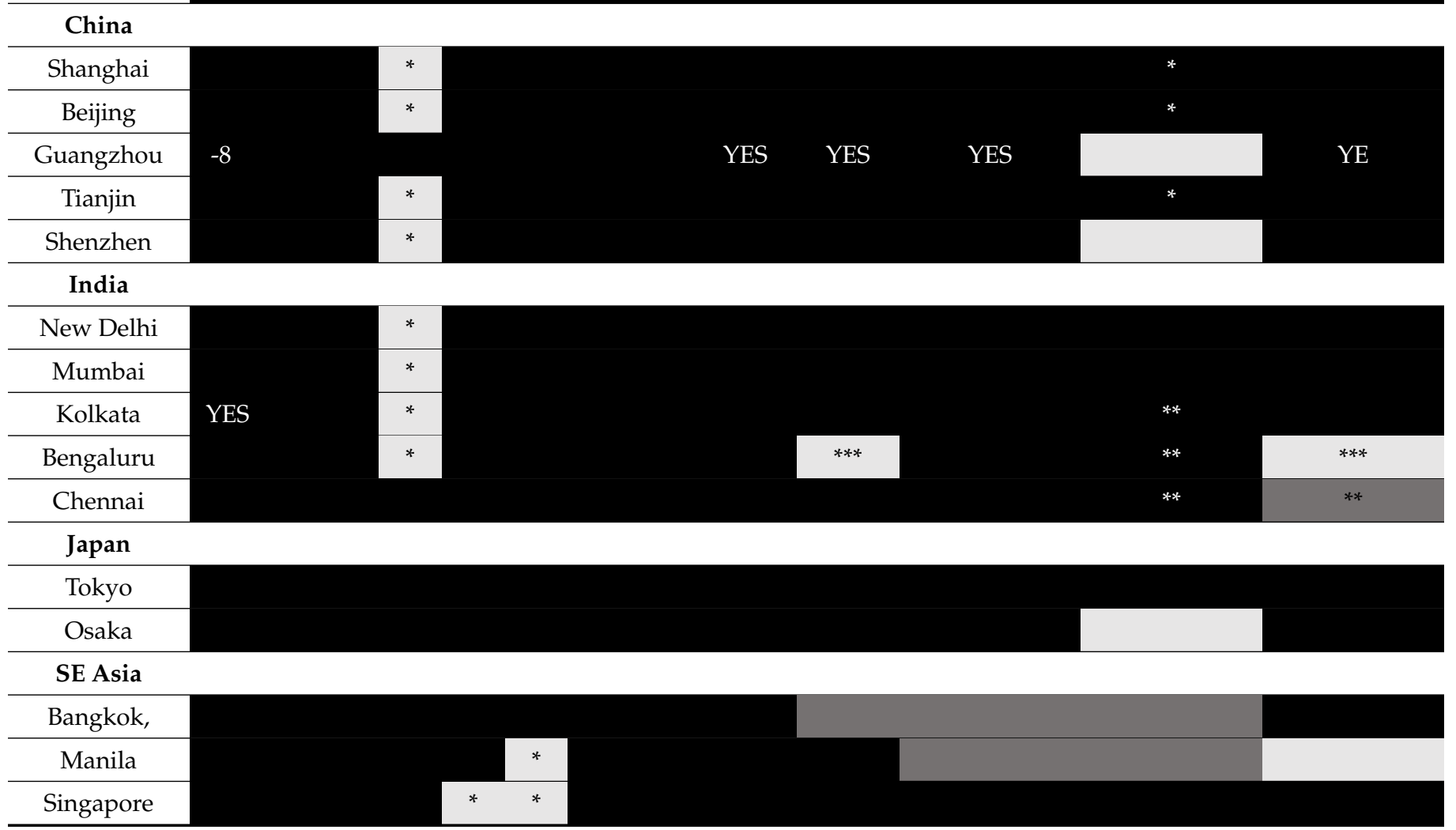

Notes: 1. Population; 2. GDP, sectoral break-up: agriculture, industry, services; 3 . household expenditure, 4. poverty/income inequality or GINI; 5 . workforce or labour participation rate; 6 . employment or unemployment rate; 7. educational level (\% of graduates), 8 . healthcare (hospitals or doctors/1000 population). ${ }^{*}$ Not applicable. ${ }^{* *}$ Non-official. ${ }^{* *}$ Available at the State level. Available. Partly available. Not available.

Chinese Cities: The sample consists of Beijing, Shanghai, Guangzhou, Tianjin and Shenzhen. Overall, the Chinese cities demonstrate robust datasets for demography and socio-economic indicators, urban data (in master plan and regional plans), energy consumption data, GHG inventory and CAPs prepared under the 13th Five-Year Plan on Climate Change (2016-2020). All the city CAPs consider both mitigation and adaptation components, use statistical approach with 2020 as the horizon/target year. In the case of Shanghai, there are climate mitigation and adaptation strategies across different sectors such as energy structure, transportation, industrial structure, green development, etc. [74]. In Beijing, the plan calls for increasing energy consumption (by 2020, when the total consumption will be lower than 76.51 million toe), followed by decreasing $\mathrm{CO}_{2}$ emissions, developing renewables and promoting energy efficiency in construction [75]. In Guangzhou, the CAP outlines actions controlling GHG emissions in different sectors, improving adaptability in agriculture, water resources and the ecological environment [76]. In Tianjin, the plan focuses on controlling GHGs by multiple measures such as low-carbon technology, carbon emission trade, energy and industrial structure improvement [77], while in Shenzhen, the CAP suggests to control GHG emissions, improve climate change adaptability and develop 
low-carbon engineering projects [78]. Only Guangzhou and Shenzhen do not have a GHG inventory.

Indian Cities: The sample cities consist of New Delhi, Mumbai, Kolkata, Chennai, Bengaluru and Hyderabad. Indian cities demonstrate availability of datasets for demography and socio-economic indicators, master plan, metropolitan/regional plans (except Kolkata and Chennai) and energy consumption data. The availability of GHG inventory and CAPs is very limited, mostly prepared by non-official agencies such as $\mathrm{PwC}$ for Kolkata [79], TERI for Navi Mumbai [80]. The national capital of New Delhi has a special status of a state, and its CAP is prepared under the mandatory State Action Plans on Climate Change framework. It considers climate mitigation and adaptation strategies for individual sectors-energy, transport, water, urban planning, agriculture, forest, and health [81] — though without any discreet statistical projections to plan for a particular target year/scenario. It includes spatial implications of climate variability, but there is no drawing of information from case study evidence. Similarly, Kolkata has a combined low-carbon and climate-resilient plan, but Chennai only has a resilience strategy document, while the megacity of Bengaluru does not have a climate plan at all.

Japanese cities: Tokyo's CAP, prepared by the Tokyo Metropolitan Government (TMG), is quite dated [82] and broadly envisions the 10-Year Project for a Carbon-Minus Tokyo. The plan is fully concentrated on climate mitigation, following a statistical approach aimed at reducing GHGs by $25 \%$ from the 2000 level by 2020 . Interestingly, it draws references from cases of other global cities such as California, London, New York and Paris. The plan includes one of the world's first cap-and-trade programs for cities, promoting low-carbon buildings, fuel efficiency regulations and renewable energy, while reducing $\mathrm{CO}_{2}$ emissions from plastics. In May 2019, the city declared its intent to become a "Zero Emission Tokyo" by 2050, aiming to limit the rise in average global temperature to $1.5^{\circ} \mathrm{C}$. It set 17 key targets to be achieved by 2030, including 47 items and 82 actions. Meanwhile, the other megacity of Osaka has a CAP prepared by the Osaka Prefecture Government (OPG) with a 10-year planning period from 2021 to 2030, targeting a GHG reduction by $40 \%$ compared to 2013 levels [83]. The plan has recently included spatial variabilities of climate change to deliberate on the impact and measures related to adaptation.

SE Asian cities: In case of Bangkok, there is no specific agency for disaster/climate responsibility, although Bangkok Metropolitan Administration (BMA) is responsible for Bangkok's development in general and preparing for their CAP. The Bangkok CAP is based on both a statistical modelling and case study approach planning both climate mitigation and adaptation strategies, with scenarios prepared for 2013 and 2020 [84]. Singapore, a city-state, has its CAP prepared by the National Climate Change Secretariat (NCCS) directly under the Prime Minister's Office. With a base year of 2005, the CAP utilizes a statistical approach in preparing GHG scenarios for 2020, 2030 and 2050, which essentially guides mitigation strategies, notably improving power generation and energy efficiency in buildings, transport, water reclamation and waste plants [85]. The city has taken several actions for urban resilience, including flood control and green and blue infrastructure crucial for climate adaptation, yet its sustenance and integration within the city's climate actions is not accounted for. In the case of Manila, the Philippines' Climate Change Commission (CCU) extensively covers the capital city under the national climate action plan for 2028 [86]. The plan statistically projects five-year GHG targets from 2010 to 2030 (base year 2009) and a projected temperature increase (for 2020 and 2050) towards preparing comprehensive mitigation and adaptation strategies over the following three phases: 2011-16, 2017-22 and 2023-28. Overall, the analysis leads to some of the most crucial findings about urban CAPs in the Asia-Pacific, as follows:

(1) The preparation of GHG inventories and CAP by urban authorities from public agencies is very limited. In spite of being prominent centers of economy and having adequate technical and financial resources, cities such as Sydney and Bengaluru fail to even have a designated climate plan. Wherever CAPs are available, these are either dated or 
possess a very short horizon period, e.g., Tokyo's climate strategy was prepared in 2007, while Chinese cities usually observe plan targets for 2020.

(2) None of the urban CAP is truly integrated in data and methods. Most plans either follow statistical modelling to evaluate and forecast GHG scenarios or spatial analysis to simulate climate variability. In fact, cities prone to wide-ranging climate risks, such as Tokyo and Singapore, do not have a climate adaptation and resilience strategy. Meanwhile, Melbourne presents a basket case of having separate plans for mitigation and adaptation prepared by the MCC with non-matching target years. Meanwhile, CAPs seldom apply a case study approach to learn from other cities. Of 17 sample cities, only Tokyo and Bangkok have partly utilized evidence from other cities.

(3) There is a clear paucity of applying the conventional MRV practice in scientific experimentation. In the cases of Beijing, New Delhi, Tianjin, Shenzhen and Sydney, their CAPs fail to demonstrate how climate variability, current risks, GHG sector emissions and their future projections are used to outline strategies.

(4) The disparate knowledge in urban climate research is concomitant with fragmentation of institutional mandates in cities. Despite all sample cities having a 5 million-plus population, they show variation in their administrative status (municipal corporation, city authority, metropolitan agency or a nationally administered area). In addition, as results indicate, there is no surety of having a specific agency or department in any of these cities that carries a functional mandate for all climate-related activities.

At the city level, the ICLAP model operationalization leads to the following research outcomes: (a) a database-, evaluation- and simulation-based ICLAP tool that enables local governments, stakeholders, academics, researchers, etc. to prepare scenarios for 2030 and 2050; (b) dissemination, which includes training of researchers, stakeholders, experts and public awareness through both popular mediums and publications as policy briefs/studies for case countries. The practical outputs from the ICLAP tool are meant to be used as an online graphical user interphase (GUI) based dashboard (see Figure 3 as a sample for New Delhi) with the following key features:

1. Visualization of local (urban-regional) climate variability of a city with maps on temperature and precipitation anomalies. These variability maps are crucial in creating multiple climate adaptation strategies.

2. GHG profiles of cities based on BAU development scenario (with graphs).

3. Adjustable GHG structures by modifying demographic, socio-economic and energy profiles (with graphs).

4. GHG of cities for high growth and realistic development pathways, year wise up to 2030 and 2050 (with graphs). The above three GHG profiles (pt.2-4) are instrumental in formulating climate-mitigation strategies for the metropolitan areas.

5. Evaluating possible policy alternatives of urban climate solutions based on global evidence of case studies (with hyperlinked references).

6. Customizable urban climate solutions for city population, sectors (building, transport, landuse, energy, waste, etc.), solution types (green buildings, integrated landuse transport, demand supply management, cool roofs, smart grids, green energy, forestation, biomass, waste to energy, etc.), type of intervention (technology/society centric, demand/supply based), optimization potential (\% GHG mitigation), governance modes (regulation, enabling, economic and voluntary). 


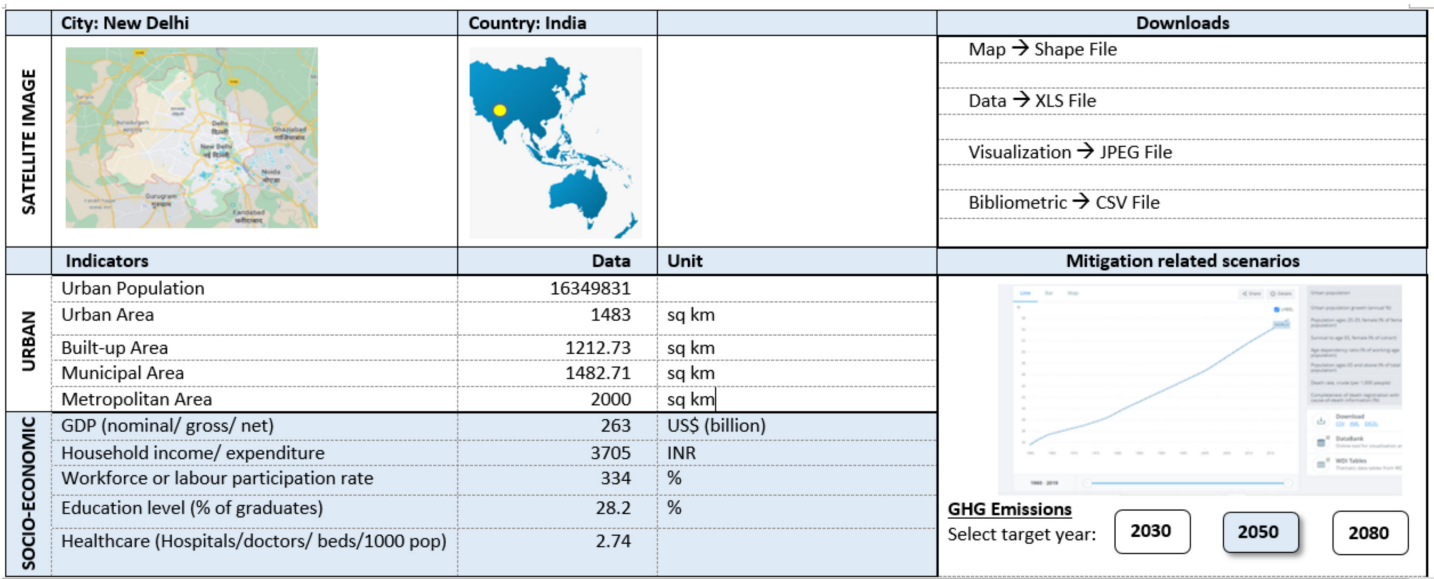

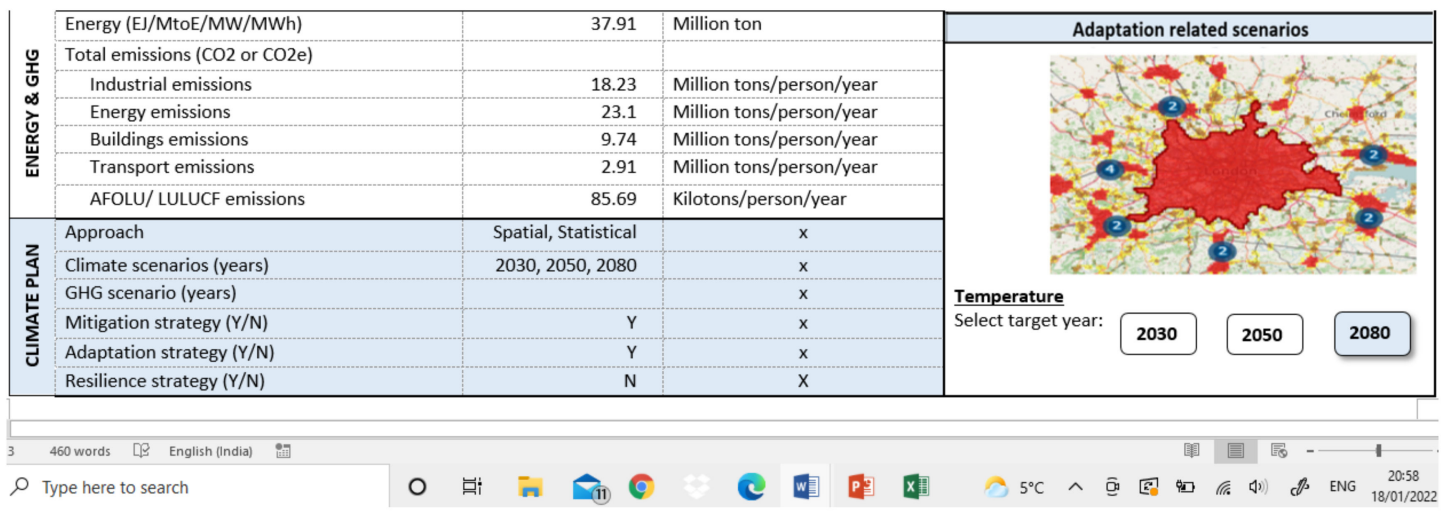

Figure 3. The dashboard result for New Delhi sample in the ICLAP Model.

\section{Conclusions}

The literature review and evidence collected from five Asia-Pacific countries in this research demonstrates that an ICLAP framework makes the process of data integrationbased decision making even more scientific, realistic and verifiable. The results of the ICLAP model are verifiable against the local climate action plans of select Asia-Pacific cities, informing existing strategies on climate, disaster mitigation, economic development, urban energy and public health. The ICLAP tool is innovative for the following three key attributes: (a) it combines quantitative meta-data from 49 Asia-Pacific cities (population, economic structure, landuse, energy, transport and GHG emissions) and climate variability (temperature, rainfall, etc.) downscaled to appropriate local scale; (b) it is evidence basedbibliometric survey and meta-analysis of a database of 20,000+ global case studies that can advise on effective local climate action; (c) it is a first-of-its-kind tool that integrates a database, evaluation (2020) and simulation for mid-term (2030) and long-term (2050) modelling features. The ICLAP empowers climate researchers, policy makers and urban bodies equally about mitigation and adaptation targets, and it evaluates possible policy alternatives (based on factual data and global case studies) as per their own circumstances. We conclude by reflecting on the long-term implications of using the ICLAP in scientific capacity development, implementing sustainable development policies at the local scale, and promoting urban climate research in the Asia-Pacific region and global change program, as discussed below:

\subsection{Scientific Capacity Development}

The ICLAP is a collaborative framework of data collection, knowledge sharing, tool development, climate strategizing and cooperation with stakeholders. It needs intensive disciplinary know-how of scientific methods for internalization into practical policy process towards a sustainable future. The ICLAP model enables collaboration between inter- 
disciplinary researchers and policy-makers, and it provides a knowledge-exchange platform that strengthens scientific capacity in urban systems. In this research, stakeholders include business, industry, non-governmental organizations and local and regional authorities across Asia-Pacific countries. This research will enhance their technical, institutional and policy-making capacities. Research visits to the selected cities for meetings with experts and stakeholders helps the timely obtaining of reliable data and insights into methods, scale, challenges and future plans of local governments in those cities. For institutional engagement and policy enhancement, the ICLAP expert workshops provide exposure to science-based policy tools for local businesses, non-governmental organizations, and local/regional governments, and in turn take into account their opinions and suggestions. In the long run, ICLAP serves a range of purposes for domestic scientific development in close interaction with the government, private sector and the general public.

\subsection{Implementation of Sustainable Development Policies}

Sustainable development policies require convergence of disparate knowledge and access to factual information to decision makers through easy-to-use applications at the local level [13]. ICLAP enables evidence-based climate planning in the Asia-Pacific cities. The relevance of this research can be gauged from the fact that it aligns with the three most significant and challenging discourses evident in the 21st century, namely sustainability (SDGs 7, 10, 11, 12, 13, 17), global climate change [5] and the New Urban Agenda/Habitat III [64]. Currently, the existing knowledge capacity of experts, communities, organizations, etc. engaged in development planning, sustainability and global change is largely normative and lacks sufficient use of empirical knowledge. ICLAP promotes the application of scientific tools to meaningfully guide development policy at the local level. By simultaneously evaluating potential climate vulnerabilities and future emission pathways, ICLAP holds multiple benefits (for the economy, health, and low-hazard/low-carbon energy alternatives) which enables localities to select alternatives beyond BAU development. For instance, planners and local governments in many developing cities still engage in large-scale greenfield development in vulnerable areas, promoting the following: energy-intensive and polluting transport modes such as cars, two-wheelers, etc.; indiscriminate change of agriculture and forest lands in and around cities; the building of disaster-resilient settlements; the control of energy consumption and GHG emissions. With support of empirical data, ICLAP would enhance cognitive and practical capacities of decision makers, spatial planners, people's representatives, etc. in prioritizing climate-responsive, low-carbon and sustainable planning solutions in cities, such as compact urban development, integrated landuse and transport planning, greater availability and accessibility of green spaces, etc.

\subsection{Fostering Urban Climate Research in Regional and Global Programmes}

The climate research agenda in the Asia-Pacific region is largely driven by the APN, notably its Fifth Strategic Plan (FSP). The methodology used in preparation of the ICLAP serves as a conduit in achieving multiple goals of the FSP [56], namely research, capacity development, science-policy interactions and community engagement. The tool directly relates to their collaborative regional research program (CRRP) topics, namely (1) climate change and climate variability and their related impacts (climate projections/downscaling, extreme events, DRR, monsoon, etc.), and (2) transition towards a sustainable future. In addition, ICLAP contributes to many of the APN's identified topics for innovative evidence-based decision-making tools [87]. ICLAP contributes to the capacity-building agenda - training and dissemination aimed at researchers and policy experts. It expands research of collaborating experts and their institutions, and is topical to the current national environmental, climate mitigation, adaptation and urban development programs of member countries such as China [88], Thailand [89] and India [81]. National action on climate change and international negotiations are interlinked and mutually reinforcing. The acknowledgment of integrated planning in the Paris Agreement [4] and the UNFCCC's AR5 Report [12] necessitates ICLAP-like decision tools beyond the Asia-Pacific 
in combating global climate change, converging with programs of several international organizations/networks, as follows: UN-Habitat, UNDP, UNEP, World Bank, Climate Works, the Climate Development Knowledge Network, WWF, the European Union, Future EarthUrbanization and Global Environmental Change (UGEC) and Earth Systems Governance (ESG), Cities Alliance, World Resources Institute, Metropolis, ICLEI-Local Governments for Sustainability, etc. In fact, ICLAP is directly relevant to UNFCCC's upcoming IPCC (AR6) report on mitigation and adaptation and the promotion of tools by the UN-Habitat Planners for Climate Action [90]. In a nutshell, the ICLAP model is instrumental in realizing global net-zero carbon reduction goals on the ground through meaningful intervention in the urban context.

Supplementary Materials: The following supporting information can be downloaded at: https: / / www.mdpi.com/article/10.3390/atmos13020247/s1, Table S1: List of 49 Five-Million+ Population Cities, Table S2: The detailed data matrix of select 17 Asia-Pacific cities showing variability of data, information and action planning in the urban climate domain.

Author Contributions: Conceptualization, M.S.; Formal analysis, M.S., L.-J.L., E.A., A.S. (Aki Suwa), R.A., A.S. (Akhilesh Surjan) and S.M.; Funding acquisition, M.S.; Investigation, L.-J.L., E.A., A.S. (Aki Suwa), R.A., A.S. (Akhilesh Surjan) and S.M.; Methodology, M.S.; Project administration, M.S.; Validation, S.M.; Visualization, M.S.; Writing-Original draft, M.S.; Writing-Review \& editing, M.S. All authors have read and agreed to the published version of the manuscript.

Funding: This research was primarily supported by grants from the Asia-Pacific Network for Global Change Research under their Collaborative Regional Research Programme (CRRP) Project No. CRRP2020-04MY-Sethi, titled "Integrated climate action planning (ICLAP) 2050 tool in Asia-Pacific cities".

Institutional Review Board Statement: Not applicable. Upon detailed review of the project, ISARD finds that the study does not involve any humans or animals.

Informed Consent Statement: Not applicable. Upon detailed review of the project, ISARD finds that the study does not involve any humans or animals.

Data Availability Statement: All data that support the findings of this study are included within the article (and any supplementary information files).

Acknowledgments: MS would like to thank unknown expert panel of the Asia-Pacific Network for Global Change Research whose inputs and feedback on the concept draft during the project screening phase helped in improvising the research framework, methodology and planned outcomes.

Conflicts of Interest: None of the authors have declared any conflict of interest.

\section{References}

1. WMO. The State of the Global Climate 2020. World Meteorological Organization. 2021. Available online: https://library.wmo. int/index.php?lvl=notice_display\&id=21880\#.YQEOJI4zbIX (accessed on 15 July 2021).

2. IPCC. Climate Change 2014-Mitigation of Climate Change: Summary for Policymakers. In Intergovernmental Panel on Climate Change; IPCC: Geneva, Switzerland, 2014.

3. UN. The Sustainable Development Goals. 2015. Available online: https://www.undp.org/content/undp/en/home/sustainabledevelopment-goals.html (accessed on 9 July 2021).

4. UNFCCC. The Paris Agreement. Bonn: United Nations Framework Convention on Climate Change. 2015. Available online: https://unfccc.int/sites/default/files/english_paris_agreement.pdf (accessed on 27 July 2021).

5. IPCC. Summary for Policymakers. In Global Warming of $1.5^{\circ} \mathrm{C}$. An IPCC Special Report on the Impacts of Global Warming of $1.5^{\circ} \mathrm{C}$ above Pre-Industrial Levels and Related Global Greenhouse Gas Emission Pathways, in the Context of Strengthening the Global Response to the Threat of Climate Change, Sustainable Development, and Efforts to Eradicate Poverty; World Meteorological Organization: Geneva, Switzerland, 2018; p. 32.

6. UNFCCC. Asia-Pacific Climate Week 2021 Sends Strong Signal to COP26. UN Climate Press Release (9 July 2021). 2021. Available online: https:/ / unfccc.int/news/asia-pacific-climate-week-2021-sends-strong-signal-to-cop26 (accessed on 28 July 2021).

7. Verisk Maplecroft. Environmental Risk Outlook. 2021. Available online: https://www.maplecroft.com/insights/analysis/ environmental-risk-outlook-2021/ (accessed on 17 October 2021).

8. ADB. Asia's Booming Cities Most at Risk from Climate Change. 2015. Available online: https://www.adb.org/news/features/ asias-booming-cities-most-risk-climate-change (accessed on 5 November 2021). 
9. Beggs, P.J.; Zhang, Y.; McGushin, A.; Trueck, S.; Linnenluecke, M.K.; Bambrick, H.; Berry, H.L.; Jay, O.; Rychetnik, L.; Hanigan, I.C.; et al. The 2021 report of the MJA-Lancet Countdown on health and climate change: Australia increasingly out on a limb. Med J. Aust. 2021, 215, 390. [CrossRef] [PubMed]

10. Farzaneh, H. Multiple benefits assessment of the clean energy development in Asian Cities. Energy Procedia 2017, 136, 8-13. [CrossRef]

11. Sethi, M.; Sharma, R.; Mohapatra, S.; Mittal, S. How to tackle complexity in urban climate resilience? Negotiating climate science, adaptation and multi-level governance in India. PLOS ONE 2021, 16, e0253904. [CrossRef] [PubMed]

12. IPCC. Synthesis Report. Contribution of working groups I. In II and III to the Fifth Assessment Report of the Intergovernmental Panel on Climate Change; IPCC: Geneva, Switzerland, 2014; p. 138.

13. Creutzig, F.; Lohrey, S.; Bai, X.; Baklanov, A.; Dawson, R.; Dhakal, S.; Lamb, W.F.; McPhearson, T.; Minx, J.; Munoz, E.; et al. Upscaling urban data science for global climate solutions. Glob. Sustain. 2019, 2, 1-25. [CrossRef]

14. Sethi, M.; Lamb, W.; Minx, J.; Creutzig, F. Climate change mitigation in cities: A systematic scoping of case studies. Environ. Res. Lett. 2020, 15, 093008. [CrossRef]

15. Gurung, G.B.; Bhandari, D. Integrated approach to climate change adaptation. J. For. Livelihood 2009, 8, 91-99.

16. Berkes, F.; Ross, H. Community Resilience: Toward an Integrated Approach. Soc. Nat. Resour. 2013, 26, 5-20. [CrossRef]

17. UNEP. Emissions Gap Report 2021: The Heat Is On-A World of Climate Promises Not Yet Delivered; United Nations Environment Programme: Nairobi, Kenya, 2021.

18. UN/GSDR-Global Sustainable Development Report (GSDR). Mobilizing Science towards Transformation Pathways for Sustainable Development; United Nations: New York, NY, USA, 2019.

19. IPCC. Mitigation of Climate Change: Contribution of Working Group III to the Fourth Assessment Report of the IPCC; Metz, B., Davidson, O.R., Bosch, P.R., Eds.; IPCC: Geneva, Switzerland, 2007.

20. Covenants of Mayors. Plans \& Actions. 2021. Available online: https://www.covenantofmayors.eu/plans-and-actions/goodpractices.html (accessed on 18 November 2021)

21. Sethi, M. Co-benefits assessment tools and research gaps. In Mainstreaming Climate Co-Benefits in Indian Cities; Springer: Singapore, 2018; pp. 47-73.

22. Farzaneh, H. Devising a Clean Energy Strategy for Asian Cities; Springer: Singapore, 2019.

23. Sethi, M. Cities and Climate Co-benefits. In Mainstreaming Climate Co-Benefits in Indian Cities; Springer: Singapore, 2018; pp. 3-45.

24. Cartaxo, T.M. From Environmental Rights to Resilience Justice. How Public Law Can Face Social-Ecological Uncertainty in Cities. Ph.D. Thesis, Universidade NOVA de Lisboa, Lisbon, Portugal, February 2020.

25. Bento, A.M.; Cropper, M.L.; Mobarak, A.M.; Vinha, K. The Effects of Urban Spatial Structure on Travel Demand in the United States. Rev. Econ. Stat. 2005, 87, 466-478. [CrossRef]

26. Schwartze, F.; Gravert, A.; Eckert, R.; Schinkel, U.; Kersten, R. Research news for climate compliant cities: The case of Ho Chi Minh City, Vietnam. In Resilient Cities; Springer: Dordrecht, The Netherlands, 2011; pp. 339-348.

27. French, M.; Trundle, A.; Korte, I.; Koto, C. Climate Resilience in Urban Informal Settlements: Towards a Transformative Upgrading Agenda. In Climate Resilient Urban Areas; Palgrave Macmillan: Cham, Switzerland, 2021; pp. 129-153.

28. Baker, A.; Brenneman, E.; Chang, H.; McPhillips, L.; Matsler, M. Spatial analysis of landscape and sociodemographic factors associated with green stormwater infrastructure distribution in Baltimore, Maryland and Portland, Oregon. Sci. Total Environ. 2019, 664, 461-473. [CrossRef]

29. Schwartze, F.; Gravert, A.; Schinkel, U.; Schwartze, R.F.; Eckert, R.; Eckert, R.K.; Kersten, R. Towards A Framework for Adaptation to Climate Change at the Municipal Level: The Case of Ho Chi Minh City. KÝY Y ẾU HộI THẢO 2010, $287-298$.

30. Anthopoulos, L. Smart utopia VS smart reality: Learning by experience from 10 smart city cases. Cities 2017, 63, 128-148. [CrossRef]

31. Horlings, J.; Marschke, M. Fishing, farming and factories: Adaptive development in coastal Cambodia. Clim. Dev. 2019, 12, 521-531. [CrossRef]

32. Belsky, E.S.; DuBroff, N.; McCue, D.; Harris, C.; McCartney, S.; Molinsky, J. Advancing inclusive and sustainable urban development: Correcting planning failures and connecting communities to capital. Jt. Cent. Hous. Stud. Harv. Univ. Camb. MA 2013, 1-113.

33. Olthuis, K.; Tartas, P.-B.; Zevenbergen, C. Design Guidelines for Upgrading Living Conditions in Wetslums. In WCFS2019; Springer: Singapore, 2020; pp. 1-18.

34. Anthopoulos, L.G. The rise of the smart city. In Understanding Smart Cities: A Tool for Smart Government or an Industrial Trick; Springer: Cham, Switzerland, 2017; pp. 5-45.

35. Darmanto, N.S.; Varquez, A.C.G.; Kawano, N.; Kanda, M. Future urban climate projection in a tropical megacity based on global climate change and local urbanization scenarios. Urban Clim. 2019, 29, 100482. [CrossRef]

36. Han, J.-Y.; Baik, J.-J.; Lee, H. Urban impacts on precipitation. Asia Pac. J. Atmos. Sci. 2014, 50, 17-30. [CrossRef]

37. László, E.; Bottyán, Z.; Szegedi, S. Long-term changes of meteorological conditions of urban heat island development in the region of Debrecen, Hungary. Theor. Appl. Climatol. 2016, 124, 365-373. [CrossRef]

38. Isa, N.A.; Salleh, S.A.; Wanmohd, W.M.N.; Chan, A. Kuala Lumpur city of tomorrow: Integration of geospatial urban climatic information in city planning. Theor. Empir. Res. Urban Manag. 2018, 13, 5-27. 
39. Varentsov, M.; Konstantinov, P.; Baklanov, A.; Esau, I.; Miles, V.; Davy, R. Anthropogenic and natural drivers of a strong winter urban heat island in a typical Arctic city. Atmospheric Chem. Phys. 2018, 18, 17573-17587. [CrossRef]

40. Daneshvar, M.R.M.; Rabbani, G.; Shirvani, S. Assessment of urban sprawl effects on regional climate change using a hybrid model of factor analysis and analytical network process in the Mashhad city, Iran. Environ. Syst. Res. 2019, 8, 1-12.

41. Cooney, C.M. Downscaling Climate Models: Sharpening the Focus on Local-Level Changes. Environ. Heal. Perspect. 2012, 120, a22-8. [CrossRef]

42. Estrada-García, R.; García-Gil, M.; Acosta, L.; Bará, S.; de Miguel, A.S.; Zamorano, J. Statistical modelling and satellite monitoring of upward light from public lighting. Light. Res. Technol. 2016, 48, 810-822. [CrossRef]

43. Chapman, S.; Watson, J.E.M.; McAlpine, C.A. Large seasonal and diurnal anthropogenic heat flux across four Australian cities. J. South. Hemisph. Earth Syst. Sci. 2016, 66, 342-360.

44. Jongtanom, Y.; Kositanont, C.; Baulert, S. Temporal Variations of Urban Heat Island Intensity in Three Major Cities, Thailand Mod. Appl. Sci. 2011, 5, 105. [CrossRef]

45. Trundle, A. Resilient cities in a Sea of Islands: Informality and climate change in the South Pacific. Cities 2020, 97,102496 [CrossRef]

46. Webb, B. The use of urban climatology in local climate change strategies: A comparative perspective. Int. Plan. Stud. 2016, 22, 68-84. [CrossRef]

47. Lenhart, J.L. Urban Climate Governance: The Role of Local Authorities; Wageningen University: Wageningen, The Netherlands, 2015.

48. Dabrowski, M.; Stead, D.; He, J.; Yu, F. Adaptive capacity of the Pearl River Delta cities in the face of the growing flood risk: Institutions, ideas and interests. Urban Stud. 2021, 58, 2683-2702. [CrossRef]

49. Torabi, E.; Dedekorkut-Howes, A.; Howes, M. Adapting or maladapting: Building resilience to climate-related disasters in coastal cities. Cities 2018, 72, 295-309. [CrossRef]

50. Anh, T.T.; Phong, T.V.G.; Tuan, T.H.; Mulenga, M. Community Consultation for Long-Term Climate-Resilient Housing in Vietnamese cities: A Comparative Case Study between Hue and Da Nang; IIED: London, UK, 2013.

51. Setiadi, R.; Baumeister, J.; Burton, P.; Nalau, J. Extending Urban Development on Water: Jakarta Case Study. Environ. Urban. ASIA 2020, 11, 247-265. [CrossRef]

52. Pickett, S.T.A.; Cadenasso, M.L.; Grove, J.M.; Nilon, C.H.; Pouyat, R.V.; Zipperer, W.C.; Costanza, R. Urban Ecological Systems: Linking Terrestrial Ecological, Physical, and Socioeconomic Components of Metropolitan Areas. Annu. Rev. Ecol. Syst. 2001, 32, 127-157. [CrossRef]

53. Irawan, A.M.; Marfai, M.A.; Nugraheni, I.R.; Gustono, S.T.; Rejeki, H.A.; Widodo, A.; Faridatunnisa, M. Comparison between averaged and localised subsidence measurements for coastal floods projection in 2050 Semarang, Indonesia. Urban Clim. 2021, 35 , 100760. [CrossRef]

54. Adu-Boateng, A. Barriers to climate change policy responses for urban areas: A study of Tamale Metropolitan Assembly, Ghana Curr. Opin. Environ. Sustain. 2015, 13, 49-57. [CrossRef]

55. APN. Strengthening the Adaptive Capacity of Local Agricultural Communities through the Development of Seasonal Climate Prediction System. APN E-Lib. 2018. Available online: https://www.apn-gcr.org/publication/project-final-report-cba2014-02 nmy-singhruck/ (accessed on 12 July 2021).

56. APN. Developing High Spatiotemporal Resolution Datasets of Low-Trophic Level Aquatic Organism and LandUse/Land-Cover in the Asia-Pacific Region: Toward an Integrated Framework for Assessing Vulnerability, Adaptation, and Mitigation of the Asia-Pacific Ecosystems to Global Climate Change. APN E-Lib. 2021. Available online: https:/ /www.apn-gcr.org/publication/ project-final-report-caf2017-rr02-cmy-siswanto/ (accessed on 8 July 2021).

57. APN Integrated. Resilience-based Planning for Climate Change Mitigation and Adaptation in Asia-Pacific Cities. APN E-Lib. 2016. Available online: https:/ / www.apn-gcr.org/resources/items/show/2011 (accessed on 10 July 2021).

58. APN. Development of an Integrated Climate Change Impact Assessment Tool for Urban Policy Makers (UrbanCLIM). APN E-Lib. 2016. Available online: https:/ /www.apn-gcr.org/resources/items/show/1749 (accessed on 10 July 2021).

59. Daniele, E.; Deborah, B.; Sliuzas, R. Measuring and understanding global human settlements patterns and processes: Innovation, progress and application. Int. J. Digit. Earth 2020, 13, 2-8. [CrossRef]

60. Esch, T.; Asamer, H.; Bachofer, F.; Balhar, J.; Boettcher, M.; Boissier, E.; Angelo, P.D.; Gevaert, C.; Hirner, A.; Jupova, K.; et al Digital world meets urban planet-new prospects for evidence-based urban studies arising from joint exploitation of big earth data, information technology and shared knowledge. Int. J. Digit. Earth 2018, 13, 136-157. [CrossRef]

61. European Commission. Atlas of the Human Planet 2018-A World of Cities; Joint Research Centre: Luxenbourg, 2018; ISBN 978-92-79-98185-2. [CrossRef]

62. UNDESA. World Population Prospects 2019: Highlights; United Nations Department for Economic and Social Affairs: New York, NY, USA, 2019.

63. UNDRR. The Sendai Framework for Disaster Risk Reduction 2015-2030; United Nations Office of Disaster Risk Reduction: Geneva, Switzerland, 2015.

64. UN-Habitat. The New Urban Agenda; The United Nations Human Settlements Programme: Nairobi, Kenya, 2016; Available online: https:/ / habitat3.org/the-new-urban-agenda/ (accessed on 25 July 2021).

65. Florczyk, A.J.; Melchiorri, M.; Corbane, C.; Schiavina, M.; Maffenini, M.; Pesaresi, M.; Kemper, T. Description of the GHS Urban Centre Database 2015. Public Release 2019, 1, 1-75. 
66. Saraswat, C.; Kumar, P.; Mishra, B.K. Assessment of stormwater runoff management practices and governance under climate change and urbanization: An analysis of Bangkok, Hanoi and Tokyo. Environ. Sci. Policy 2016, 64, 101-117. [CrossRef]

67. Fujimori, S.; Masui, T.; Matsuoka, Y. Development of a global computable general equilibrium model coupled with detailed energy end-use technology. Appl. Energy 2014, 128, 296-306. [CrossRef]

68. Lamb, W.F.; Callaghan, M.W.; Creutzig, F.; Khosla, R.; Minx, J.C. The literature landscape on $1.5^{\circ} \mathrm{C}$ climate change and cities. Curr. Opin. Environ. Sustain. 2018, 30, 26-34. [CrossRef]

69. Lamb, W.F.; Creutzig, F.; Callaghan, M.W.; Minx, J.C. Learning about urban climate solutions from case studies. Nat. Clim. Change 2019, 9, 279-287. [CrossRef]

70. UN-Habitat. Cities and Climate Change: Global Report on Human Settlements; Routledge: London, UK, 2011.

71. MCC. Climate Change Mitigation Strategy 2050. Melbourne City Council. 2018. Available online: https://www.melbourne.vic. gov.au/sitecollectiondocuments / climate-change-mitigation-strategy-2050.pdf (accessed on 15 June 2021).

72. MCC. Climate Change Adaptation Strategy Refresh. Melbourne City Council. 2017. Available online: https://www.melbourne vic.gov.au/sitecollectiondocuments/climate-change-adaptation-strategy-refresh-2017.pdf (accessed on 15 June 2021).

73. Sydney City Council. Draft Environmental Strategy 2021-2025. Sydney: Sydney City Council. 2018. Available online: https: //www.cityofsydney.nsw.gov.au/vision-setting/have-your-say-environmental-strategy-2021-2025 (accessed on 17 June 2021).

74. SMDRC-Shanghai Municipal Development and Reform Commission. Shanghai's Key Work Arrangements for Energy Conservation, Emission Reduction and Climate Change in 2020. 2020. Available online: https://www.shanghai.gov.cn/nw12344/2020081 3/0001-12344_64938.html (accessed on 14 July 2021).

75. PGBM-The People's Government of Beijing Municipality. Plan for Energy Saving and Consumption Reduction and Climate Change Addressing in Beijing during the 13th Five-Year Plan Period. Energy Conservation and Environmental Protection. 2016. Available online: http://www.china-nengyuan.com/news/97698.html (accessed on 14 July 2021).

76. GDRC-Guangzhou Development and Reform Commission. Guangdong's 13th Five-Year Plan on Climate Change. 2017. Available online: http:/ /drc.gd.gov.cn/gkmlpt/content/1/1060/post_1060342.html\#829 (accessed on 14 July 2021).

77. PGTM-The People's Government of Tianjin Municipality. Implementation Plan of Greenhouse Gas Emission Control in Tianjin during the 13th Five-Year Plan Period. 2017. Available online: http:/ /www.tj.gov.cn/zwgk/szfwj/tjsrmzfbgt/202005/t2020051 9 2370300.html (accessed on 14 July 2021).

78. SDRC-Shenzhen Development and Reform Commission. Shenzhen's 13th Five-Year Plan on Climate Change. 2017. Available online: http://www.szns.gov.cn/xxgk/qzfxxgkml/ghjh/fzgh/content/post_3731395.html (accessed on 14 July 2021).

79. PWC. Roadmap for Low Carbon and Climate Resilient Kolkata. Kolkata: PricewaterhouseCoopers Private Limited. 2016. Available online: https:/ / www.vetiver.org/IND_URBAN_RESILIENCE/IND_2_Road\%20Map\%20for\%20Climate\%20Resilient $\%$ 20Kolkata.pdf (accessed on 4 June 2021).

80. TERI. Carbon Inventory of Navi Mumbai. Mumbai: TERI. 2013. Available online: https://www.teriin.org/sites/default/files/20 18-02/2012MC03\%20Carbon\%20Inventory_Navi\%20Mumbai.pdf (accessed on 4 June 2021).

81. GNCTD. Delhi state action plan on climate change. 2017. Available online: http://moef.gov.in/wp-content/uploads/2017/08/ Delhi-State-Action-Plan-on-Cimate-Change.pdf (accessed on 8 July 2021).

82. TMG. Tokyo Climate Change Strategy: Progress Report and Future Vision. 2007. Available online: https:/ / www.kankyo.metro tokyo.lg.jp/en/climate/index.files/Tokyo_climate_change_strategy_progress_r.pdf (accessed on 6 June 2021).

83. OPG. Osaka Prefecture Global Warming Countermeasures Implementation Plan (Area Measures). 2021. Available online: https: / / www.iges.or.jp/sites/default/files/inline-files/S2-4_Mr.\%20Ryutaro\%20Michigami_Osaka_city.pdf (accessed on 8 June 2021).

84. BMA. Bangkok Master Plan on Climate Change 2013-2023. 2012. Available online: http://www.start.chula.ac.th/start/images/ Champ/Day1/Bangkok-Master-Plan-on-Climate-Change_31July2017.pdf (accessed on 8 June 2021).

85. NCCS. Singapore's Climate Action Plan: Take Action Today, For a Carbon-Efficient Singapore. National Climate Change Secretariat Prime Minister's Office, Singapore. 2016. Available online: https:/ /www.nccs.gov.sg/docs/default-source/publications / take-action-today-for-a-carbon-efficient-singapore.pdf (accessed on 15 June 2021).

86. CCU. National Climate Change Action Plan (NCCAP 2011-2028). Climate Change Commission. 2011. Available online: http:/ / climate.emb.gov.ph/wp-content/uploads/2016/06/NCCAP-1.pdf (accessed on 12 June 2021).

87. APN. Calls for Proposals under the CRRP and CAPaBLE Programmes. 2019. Available online: https://www.apn-gcr.org/news/ 2019-calls-for-proposals-under-the-crrp-and-capable-programmes/ (accessed on 5 July 2021).

88. NDRC. China's National Climate Change Programme. Beijing: National Development and Reform Commission People's Republic of China. 2007. Available online: http:/ / www.ccchina.org.cn/WebSite/CCChina/UpFile/File188.pdf (accessed on 26 June 2021).

89. ONEP. Thailand: Climate Change Master Plan. Bangkok: Office of Natural Resources and Environmental Policy and Planning. 2015. Available online: https://www.preventionweb.net/english/professional/policies/v.php?id=60582 (accessed on 24 July 2021).

90. UN-Habitat. Planning for Climate Change-Toolkit; UN Centre for Human Settlements: Nairobi, Kenya, 2014. 